Praca poglądowa/Review

\title{
Nowe metody diagnostyczne w prognozowaniu i śledzeniu odpowiedzi na leczenie inhibitorami kinaz tyrozynowych przewlekłej białaczki szpikowej
}

\section{Recent developments in diagnostics and monitoring of tyrosine kinase inhibitors treatment response of chronic myeloid leukemia}

\author{
Joanna Wącław, Tomasz Sacha* \\ Klinika Hematologii Collegium Medicum Uniwersytetu Jagiellońskiego w Krakowie, Polska
}

INFORMACJE O ARTYKULE

Historia artykułu:

Otrzymano: 25.03.2016

Zaakceptowano: 19.04 .2016

Dostępne online: 28.04.2016

Słowa kluczowe:

- $\mathrm{CML}$

- IKT

- halving time

- monitorowanie leczenia

- digital PCR

Keywords:

- CML

- TKI

- Halving time

- Treatment response monitoring

- Digital PCR

\begin{abstract}
A B S T R A C T
Techniques of molecular biology are of key importance in diagnostics and monitoring of tyrosine kinase inhibitors (TKIs) treatment response of chronic myeloid leukemia (CML). Although much has already been achieved in this field, new prognostic factors and developments in laboratory methods are constantly emerging.

Halving time is a new prognostic factor defined as the rate of BCR-ABL1 decline from baseline, assessed by estimating the number of days over which BCR-ABL1 halved. Among patients with $>10 \%$ BCR-ABL1 at 3 months of therapy with TKI, the poorest-risk group can be distinguished by the slow rate of BCR-ABL1 decline from baseline. More common use of techniques, such as the whole exome sequencing and transcriptome sequencing will enable assessment of patients' genetic variation at diagnosis and may contribute to a prognostic score that will allow for optimization of therapy. Digital PCR built on traditional PCR provides highly sensitive absolute quantification of BCR-ABL1 transcript level without the need for standard curves and could further improve the treatment results in patients with $\mathrm{CML}$
\end{abstract}

(c) 2016 Polskie Towarzystwo Hematologów i Transfuzjologów, Instytut Hematologii i Transfuzjologii. Published by Elsevier Sp. z o.o. All rights reserved.

\footnotetext{
* Adres do korespondencji: Katedra Hematologii CMUJ, ul Kopernika 17, 31-501 Kraków, Polska. Tel.: +48 124247600 ; fax: +48 124247426 .

Adres email: sachatom@gmail.com (T. Sacha). http://dx.doi.org/10.1016/j.achaem.2016.04.007 0001-5814/@ 2016 Polskie Towarzystwo Hematologów i Transfuzjologów, Instytut Hematologii i Transfuzjologii. Published by Elsevier Sp. $\mathrm{z}$ o.o. All rights reserved.
} 


\section{Wprowadzenie}

Przewlekła białaczka szpikowa (CML; chronic myeloid leukemia) jest chorobą krwiotwórczej komórki macierzystej szpiku charakteryzującą się występowaniem onkogenu fuzyjnego BCRABL1, kodującego białko o konstytutywnej aktywności kinazy tyrozynowej [1]. W ocenie rokowania i monitorowaniu odpowiedzi na leczenie inhibitorami kinaz tyrozynowych (IKT) kluczową rolę odgrywają badania diagnostyczne prowadzone metodami biologii molekularnej, a zwłaszcza RQ-PCR. Brak optymalnej odpowiedzi molekularnej, szczególnie w początkowej fazie terapii IKT, pozwala zidentyfikować pacjentów o dużym ryzyku niepowodzenia leczenia i progresji choroby [2]. Z kolei osiągnięcie przez pacjenta trwałej, głębokiej odpowiedzi molekularnej może być przesłanką do podjęcia próby odstawienia leczenia IKT [3, 4]. Warunkuje to konieczność poszukiwania coraz lepszych czynników prognostycznych, a także doskonalenia aktualnie stosowanych i wprowadzania nowych metod w diagnostyce molekularnej CML

\section{Czas $\mathbf{5 0 \%}$ redukcji poziomu transkryptu BCR-ABL1 (HT; halving time) - nowy wskaźnik prognostyczny w leczeniu CML}

Wczesna odpowiedź molekularna (EMR; early molecular response), definiowana jako poziom transkryptu po pierwszych 3 miesiącach terapii IKT, jest obecnie jednym $\mathrm{z}$ najważniejszych czynników prognostycznych u chorych na przewlekłą białaczkę szpikową w fazie przewlekłej (CML-CP; CMLchronic phase). Redukcja poziomu transkryptu BCR-ABL1 po pierwszych 3 miesiącach terapii IKT do $\leq 10 \%$ wiąże się z większą szansą uzyskania większej odpowiedzi molekularnej (MMR), mniejszym skumulowanym odsetkiem niepowodzenia terapii oraz większą szansą na uzyskanie długotrwałego przeżycia wolnego od zdarzeń niepożądanych (EFS; Event-Free Survival) [2]. Marin i wsp. wykazali, że poziom transkryptu BCR-ABL1 $>10 \%$ w 3 . miesiącu leczenia koreluje z niższym odsetkiem uzyskiwanych przeżyć wolnych od progresji (PFS) oraz przeżyć całkowitych (OS) u pacjentów z CML-CP leczonych imatynibem. Co więcej, w analizie wieloczynnikowej EMR miała istotnie większe znaczenie rokownicze niż wszystkie pozostałe uwzględnione czynniki prognostyczne [5]. Kolejne badania potwierdziły istotny wpływ EMR na rokowanie u pacjentów leczonych nilotynibem oraz dazatynibem zarówno w pierwszej, jak i drugiej linii [6, 7]. W efekcie EMR została uwzględniona w ocenie odpowiedzi na leczenie IKT w rekomendacjach ELN, NCCN oraz PALG [8-10]. Przy czym pomiędzy zaleceniami tych towarzystw istnieją rozbieżności. NCCN oraz PALG rekomendują zmianę IKT już $\mathrm{w}$ trzecim miesiącu terapii, jeśli poziom transkryptu BCRABL1 przekracza 10\%, zakładając, że wykrycie takiego poziomu w dwóch niezależnie wykonanych testach (PALG) oznacza niepowodzenie leczenia [9, 10]. ELN wskazuje, że pojedyncze oznaczenie liczby kopii transkryptu w trzecim miesiącu nie pozwala jeszcze na rozpoznanie niepowodzenia terapii, a jedynie stanowi ostrzeżenie i zaleca wykonanie dodatkowego badania molekularnego oraz zmianę leku, jeśli poziom transkryptu BCR-ABL1 >10\% utrzymuje się w 6 . miesiącu od rozpoczęcia terapii [8].

Obserwacje ostatnich lat wskazują jednak, że nie $\mathrm{u}$ wszystkich chorych $\mathrm{z}$ poziomem transkryptu BCR-ABL1 $>10 \%$ po pierwszych 3 miesiącach leczenia IKT rokowanie jest niekorzystne. Badania opublikowane niedawno dowiodły, że istotne znaczenie dla rokowania pacjenta ma również wczesna dynamika spadku poziomu transkryptu. Hanfstein i wsp. w pracy przedstawionej podczas dorocznego sympozjum ASH w 2013 r. wykazali, że u chorych na CMLCP leczonych imatynibem przyjęcie jako punktu odcięcia redukcji poziomu transkryptu BCR-ABL1 w trzecim miesiącu terapii do 0,35 wartości $\mathrm{W}$ momencie diagnozy (redukcja 0,46 log) jest niezależnym czynnikiem prognostycznym z ryzykiem względnym (HR) 5,6 (95\%CI 2,3-13,4; p < 0,001 dla PFS) i pozwala wyodrębnić grupy chorych o ryzyku wysokim (16\% pacjentów; 5-letnie PFS oraz OS odpowiednio: $77 \%$ i $83 \%$ ) i niskim (84\% pacjentów; 5-letnie PFS oraz OS odpowiednio: $96 \%$ i 98\%) [11]. Pojęcie halving time definiowane jako czas potrzebny do uzyskania 50\% redukcji poziomu transkryptu BCR-ABL1 względem wartości wyjściowej $\mathrm{u}$ indywidualnego pacjenta wprowadziła Branford i wsp. [12]. HT obliczany jest za pomocą formuły $c=-\ln (2) / k$, gdzie $c$ to halving time, $k$ to stopień zmiany poziomu transkryptu względem wartości wyjściowej podzielony przez liczbę dni od rozpoczęciu leczenia imatynibem do wykonania kontrolnego badania molekularnego; $k=[\ln (b)-\ln (a)] / d$, gdzie $a$ to wyjściowa wartość poziomu transkryptu BCR-ABL1, $b$ to wartość poziomu transkryptu w momencie wykonania kontrolnego badania molekularnego, a $d$ to liczba dni pomiędzy tymi pomiarami. Wyniki badania Branford i wsp. po raz kolejny potwierdziły prognostyczne znaczenie poziomu transkryptu BCR-ABL1 w 3. miesiącu terapii ( $\leq 10 \%$ vs $>10 \%$ ), jednakże analiza przeprowadzona w grupie 95 chorych $\mathrm{z}$ poziomem transkryptu BCR-ABL1 w trzecim miesiącu $>10 \%$ wykazała, że pacjenci z HT $<76$ dni $(\mathrm{n}=74)$ mieli istotnie lepsze rezultaty leczenia niż chorzy z HT $>76$ dni ( $n=21)$. Czteroletnie OS, wynosiło odpowiednio 95\% i 58\%, $\mathrm{p}=0,0002$; PFS, 92\% i 63\%, p=0,008; przeżycie wolne od niepowodzenia (FFS) 59\% i 6\%, p <0,0001; a większa odpowiedź molekularna, $54 \%$ i $5 \%, p=0,008$ ) (Ryc. 1) $\mathrm{W}$ dodatkowej analizie wieloczynnikowej uwzględniającej m.in. grupę ryzyka pacjenta wg wskaźnika Sokala oraz stosowaną dawkę imatynibu (400 mg/d lub $600 \mathrm{mg} / \mathrm{d}$ albo $800 \mathrm{mg} / \mathrm{d}$ ), HT był jedynym czynnikiem prognostycznym istotnie wpływającym na odsetki OS, PFS, FFS oraz MMR ocenianych po 4 latach leczenia $w$ tej grupie chorych [12]. W kolejnym badaniu zaprezentowanym podczas sympozjum ASH w 2014 r. Branford i wsp. analizowali znaczenie HT po pierwszym miesiącu leczenia imatynibem u 521 pacjentów chorych na CML-CP w kontekście innych czynników prognostycznych, takich jak: wiek, płeć, wskaźnik Sokala oraz stosowana dawka imatynibu $(400 \mathrm{mg} / \mathrm{d}$ lub $600 \mathrm{mg} / \mathrm{d}$ albo $800 \mathrm{mg} / \mathrm{d}$ ). Pacjenci z HT $\leq 11$ dni uzyskiwali istotnie większe odsetki MMR po 12 miesiącach leczenia, $\mathrm{MR}^{4,5}$ oraz 4-letniego FFS. W jedno- i wielowariantowej analizie regresji tylko wskaźnik Sokala i HT w 1. miesiącu były czynnikami niezależnie prognozującymi MMR, $\mathrm{MR}^{4,5}$ i FFS. Co więcej, pacjenci wysokiego ryzyka wg Sokala z HT 

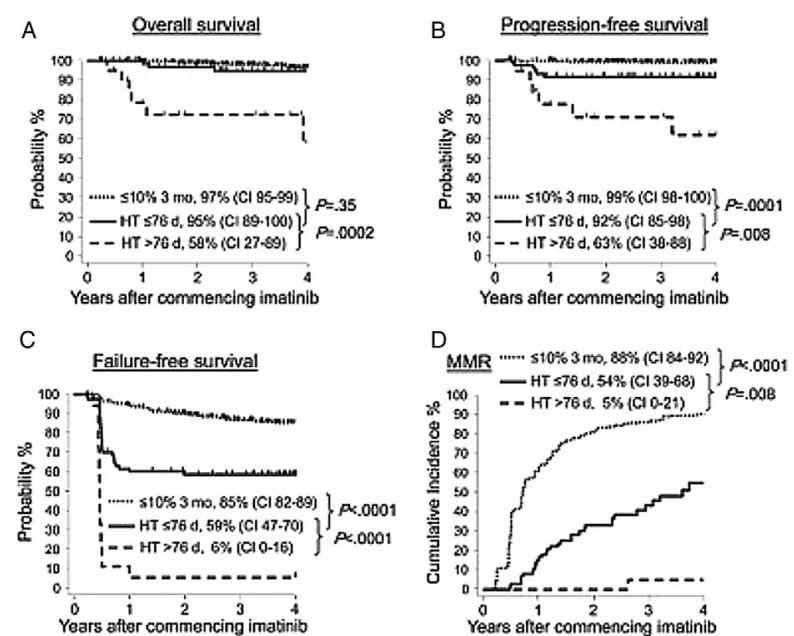

Ryc. 1 - Przeżycie całkowite, wolne od progresji, wolne od niepowodzenia oraz szansa na osiągnięcie MMR w zależności od HT po 3 miesiącach terapii u chorych z poziomem transkryptu BCR-ABL1 po 3 miesiącach terapii >10\% [12]

Fig. 1 - Overall survival, Progression-free survival, Failure-free survival and MMR according to HT in patients with BCR-ABL1 values $>10 \%$ at 3 months [12]

$\leq 11$ dni mieli równie dobre rokowanie jak chorzy z grupy niskiego ryzyka, a pacjenci z grupy pośredniego i niskiego ryzyka wg Sokala, ale z HT po miesiącu $>29$ dni, uzyskiwali znacznie mniejsze odsetki MMR, $\mathrm{MR}^{4,5}$ i FFS niż oczekiwane (Ryc. 2) [13].
Należy zauważyć, że u części pacjentów z poziomem transkryptu BCR-ABL1 w 3. miesiącu terapii $>10 \%$ i stałą szybkością redukcji poziomu transkryptu stosunkowo niewielkie przesunięcie w czasie terminu pobrania próbki do badania molekularnego może wpłynąć na uzyskany wynik

\section{Rapid initial decline - better outcome for high Sokal risk pts}

A FFS-High Sokal risk

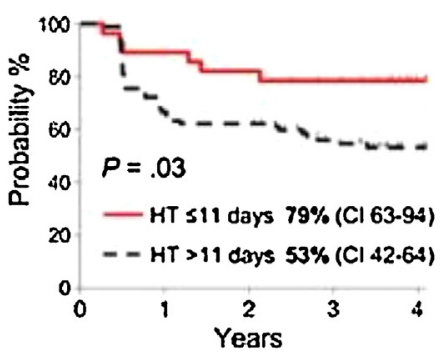

Slow initial decline - poorer rate of optimal response (12 mo MMR) for low and intermediate Sokal risk pts
B MMR-High Sokal risk

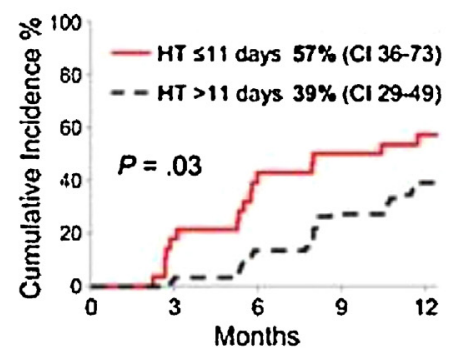

D MMR - Low Sokal risk

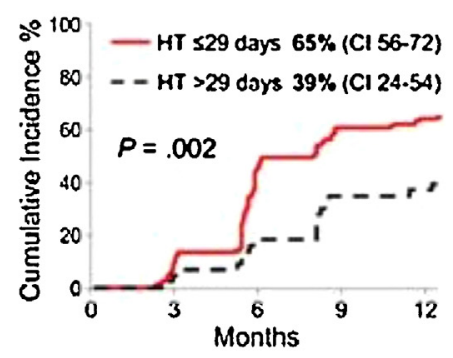

C $\underline{M R^{4.5}}$ - High Sokal risk

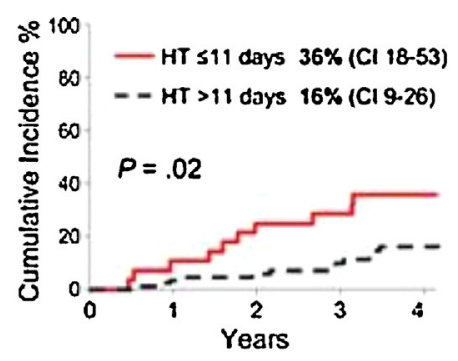

E MMR - Intermediate Sokal risk

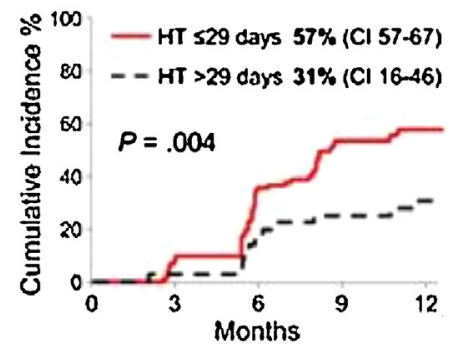

Ryc. 2 - Przeżycie wolne od niepowodzenia, szansa na osiągnięcie MMR oraz $\mathrm{MR}^{4,5} \mathrm{w}$ zależności od od HT po 1 miesiącu terapii u pacjentów z wysokim (A, B, C), niskim (D) oraz pośrednim (E) ryzykiem wg wskaźnika Sokala [13] Fig. 2 - Failure-free survival, MMR and $M R^{4.5}$ according to $H T$ after $1^{\text {st }}$ month of therapy in patients with high (A, B, C), low (D) and intermediate (E) Sokal risk [13] 
i tym samym zmienić kategorię odpowiedzi uzyskanej przez pacjenta (np. z ostrzeżenia lub niepowodzenia na optymalną i odwrotnie). W rzeczywistości wynik badania poziomu transkryptu BCR-ABL1 w 3. miesiącu terapii będzie zawsze dotyczyć próbki krwi pobranej od chorego w pewnym przedziale czasowym, w którym wykonano kontrolne badanie molekularne. W przytoczonym badaniu był to np. okres pomiędzy 70. a 126. dniem po rozpoczęciu leczenia imatynibem [12].

Warto podkreślić, że podobnie jak uzyskanie redukcji poziomu transkryptu BCR-ABL1 po pierwszych 3 miesiącach leczenia IKT do $\leq 10 \%$ (IS), HT także nie jest idealnym czynnikiem prognostycznym. Formuła służąca do obliczania HT zakłada stałe tempo zmiany poziomu transkryptu w początkowym okresie leczenia, co nie zawsze musi znajdować odzwierciedlenie w rzeczywistości [14]. Ponadto istnieją pewne ograniczenia metodologiczne związane z używanym w trakcie oznaczeń metodą RQ-PCR genem referencyjnym. Prawidłowe obliczenie HT wymaga znajomości poziomu transkryptu BCR-ABL1 oznaczonego precyzyjnie metodą RQ-PCR w momencie rozpoczęcia leczenia, co nie zawsze jest możliwe przy użyciu ABL1 jako genu kontrolnego. Wynika to ze specyfiki badania RQ-PCR wykorzystującego ABL1 jako gen kontrolny. Amplikony ABL1 pochodzą wówczas zarówno $z$ mRNA transkryptów ABL1, jak i BCR-ABL1. W chwili rozpoznania CML, kiedy ekspresja BCR-ABL1 jest zwykle wysoka, większość amplikonów w PCR pochodzi z mRNA BCR-ABL1, co oznacza, że maksymalny możliwy do zmierzenia poziom transkryptu jest równy $100 \%$. Właściwe obliczenie HT dopuszcza poziom transkryptu powyżej 100\% i odnosi się do wartości początkowej oznaczonej u pojedynczego pacjenta, a nie do wartości uśrednionej skalkulowanej zgodnie z dotychczasowymi zaleceniami European Lekemia Net przyjętej do obliczeń redukcji logarytmicznej BCR-ABL1 w trakcie leczenia IKT. Z tego powodu Hanfstein i wsp. we wspomnianym już badaniu przeprowadzonym w ramach German CML-Study IV zaproponowali beta glukuronidazę (GUS) jako gen referencyjny w oznaczeniach dynamiki spadku poziomu transkryptu BCR-ABL1 [15]. Grupa japońskich badaczy, która oceniała prognostyczną wartość HT u 52 pacjentów z CML-CP leczonych w pierwszej linii dazatynibem, zastosowała $z$ kolei jako gen kontrolny gen aldehydu-3-fosfoglicerynowego (GAPDH). W tym badaniu HT $\leq 14$ dni był czynnikiem zwiększającym prawdopodobieństwo osiągnięcia MMR w 12. miesiącu leczenia i jedynym spośród kilku uwzględnionych w analizie czynnikiem prognozującym osiągnięcie głębokiej odpowiedzi molekularnej (definiowanej jako $<50$ kopii transkryptu

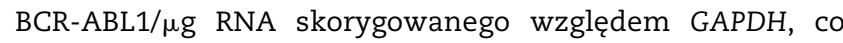
odpowiada $<0,01 \%$ wg Międzynarodowej Skali (IS) [16].

\section{Mutacje o znaczeniu prognostycznym dla odpowiedzi na leczenie IKT i oceny ryzyka progresji choroby}

Jakkolwiek znanych jest już kilka czynników pozwalających prognozować odpowiedź na leczenie IKT i ryzyko progresji choroby u pacjentów z CML-CP, nieustannie trwają poszukiwania nowych, doskonalszych. Dotyczy to zwłaszcza grupy pacjentów, którzy wg aktualnie stosowanych wskaźników obciążeni są niekorzystnym rokowaniem. Podczas ostatniego, 57 dorocznego sympozjum ASH prezentowano liczne doniesienia na ten temat.

Marum i wsp. badali znaczenie zmienności genetycznej u pacjentów z CML-CP leczonych w pierwszej linii imatynibem $(n=528)$ lub nilotynibem $(n=83)$. Za pomocą metody celowanego sekwencjonowania amplikonów (targeted amplicon sequencing) oceniano 35 genów kodujących białka związane $\mathrm{z}$ apoptozą indukowaną przez IKT (w tym BIM, BAD i BCL2) oraz metabolizmem leków, a także geny o udowodnionym już znaczeniu w patogenezie nowotworów hematologicznych (w tym ASXL1 i TET2). Do dalszej analizy wybrano 200 pojedynczych wariantów nukleotydowych (SNPs; single nucleotide polymorphisms). W grupie pacjentów leczonych imatynibem $\mathrm{w}$ analizie uwzględniono dodatkowe czynniki, tj. wiek, płeć, ryzyko wg wskaźnika Sokala oraz stosowaną dawkę leku (400 mg/d lub 600 mg/d albo $800 \mathrm{mg} / \mathrm{d}$ ). W analizie wielowariantowej wskaźnik Sokala, wariant rs4911231 genu ASXL1 i rs686952 genu BIM były niezależnymi czynnikami prognozującymi MMR w 12. miesiącu, MR4 w 48. miesiącu oraz $\mathrm{MR}^{4,5}$, a także FFS. Zidentyfikowano trzy grupy ryzyka w zależności od wariantu genotypu: dobre: ASXL1 T/T \& BIM A/A + A/C (16\% pacjentów), pośrednie: ASXL1 C/C + T/C \& BIM A/A + A/C lub ASXL1 T/T \& BIM C/C (46\% pacjentów) oraz niekorzystne: ASXL1 C/C + T/C \& BIM C/C (37\% pacjentów). Pomiędzy poszczególnymi grupami ryzyka występowały istotne różnice $\mathrm{w}$ zakresie osiąganych odsetków EMR, MMR w 12. oraz MR4 w 48. miesiącu, a także $\mathrm{MR}^{4,5}$ i FFS. Co więcej, $\mathrm{w}$ dodatkowej analizie przeprowadzonej w grupie pacjentów wysokiego ryzyka wg Sokala, wariant genotypu nadal zachowywał istotną wartość prognostyczną w zakresie uzyskiwanych odpowiedzi. Co ciekawe, w grupie pacjentów leczonych nilotynibem nie stwierdzono istotnego wpływu wariantu genotypu na uzyskiwane odpowiedzi [17]. Może to sugerować, że zastosowanie silniejszego IKT znosi wpływ niekorzystnego wariantu genotypu.

Inne badanie miało na celu identyfikację mutacji, których wykrycie już w momencie diagnozy CML-CP zwiększałoby ryzyko progresji choroby do fazy kryzy blastycznej (BC; blastic crisis). Badana grupa składała się z: 28 pacjentów z CML-CP leczonych w pierwszej linii imatynibem (u 14 $\mathrm{z}$ nich doszło następnie do progresji do BC z medianą czasu do progresji 9 miesięcy, u kolejnych 14 uzyskano optymalną odpowiedź na leczenie - MMR w 6. miesiącu terapii), 2 chorych, u których rozpoznano chorobę w fazie akceleracji (AP), 2 pacjentów zdiagnozowanych w fazie BC oraz retrospektywnego materiału pochodzącego od 5 pacjentów z BC. Zastosowano metodę sekwencjonowania eksomu (WES; whole exome sequencing) i transkryptomu (RNAseq; transcriptome sequencing), porównując badany materiał $\mathrm{z}$ kontrolnym prawidłowym. U 4 chorych zdiagnozowanych w fazie AC/BC wykryto mutacje w genach o udowodnionym już znaczeniu w patogenezie nowotworów (tzw. cancer genes), takich jak: CBFB-MYH11, BCORL1, GATA2 i PTPRT oraz SMARCA1. U 11 pacjentów spośród 28 zdiagnozowanych w fazie przewlekłej wykryto onkogenne mutacje w genach IDH1, MLL2, TP53, ASXL1, EZH2, SETD1B, CHD1 i 4 inne dotychczas nieopisywane. U 9 spośród tych 11 osób doszło do rozwoju BC (mediana czasu do progresji wyniosła 6 miesięcy). Częstość 
progresji była znamiennie większa u pacjentów z ww. mutacjami niż bez nich (9/11 [82\%] us 5/17 [29\%], $p=0,02)$. $\mathrm{U}$ pacjentów $\mathrm{w}$ fazie kryzy blastycznej zidentyfikowano powtarzające się mutacje w 6 genach: ASXL1, BCORL1, RUNX1, GATA2, MLL i UBE2A. Na podstawie analizy wyników omówionego badania można wnioskować, że kluczową rolę w patogenezie CML odgrywają mechanizmy regulacji epigenetycznej i modyfikacji chromatyny, a także procesy ubikwitynacji i transportu na zewnątrz jądra komórkowego. $\mathrm{U}$ chorych $\mathrm{w}$ fazie $\mathrm{BC}$ obok mutacji $\mathrm{w}$ domenie kinazowej BCR-ABL1 jednocześnie pojawiały się mutacje w tzw. cancer genes, co wskazuje na złożoność mechanizmów progresji CML [18].

Nowe narzędzia w diagnostyce molekularnej CML

Doskonalenie metod diagnostyki, monitorowania i terapii CML nie byłoby możliwe, gdyby nie jednoczesny rozwój narzędzi służących do szeroko rozumianych badań molekularnych. Grupa badaczy z Oxfordu stworzyła metodę analizy transkryptomu w pojedynczej komórce (Single Cell Whole Transcriptome Analysis), umożliwiającą amplifikację i wykrywanie transkryptu BCR-ABL1 na poziomie pojedynczych komórek. 100-procentową skuteczność metody w wykrywaniu transkryptu potwierdzono przy użyciu linii komórkowej BCR-ABL +ve K562. Następnie zbadano 40 komórek macierzystych pochodzących od pacjenta z CML, który osiągnął całkowitą odpowiedź cytogenetyczną (CCyR; Complete Cytogenetic Response) po 3 miesiącach terapii IKT. Gen BCR-ABL1 wykryto w 16 spośród nich. Analizowano średnio 3,3 mln odczytów z pojedynczej komórki i porównano komórki BCR/ ABL+ i BCR/ABL-, co umożliwiło wykrycie wielu genów różniących się ekspresją. Ekspresję tych najbardziej interesujących pod względem biologii komórki zweryfikowano przy użyciu RQ-PCR, uzyskując 80\% stopień zgodności. Opisywana metoda umożliwiła ocenę profilu ekspresji genów w komórkach macierzystych białaczki opornych na działanie IKT. Dzięki temu pozwoliła na wykrycie wielu genów - kandydatów kodujących białka będące potencjalnymi punktami uchwytu dla działania nowych leków. Wreszcie, analiza transkryptomu komórek pacjenta z progresją do fazy kryzy blastycznej dała wgląd w kaskadę prowadzących do niej zdarzeń molekularnych [19].

W niniejszym artykule wielokrotnie podkreślano znaczenie prognostyczne EMR i pozytywne konsekwencje osiągnięcia w trzecim miesiącu terapii poziomu transkryptu BCR-ABL1 <10\% (IS). Interpretacja wyniku badania poziomu transkryptu może jednak zależeć od metody służącej do jego wykrywania. Przy użyciu całkowicie automatycznego systemu detekcji transkryptu BCR-ABL1 GeneXpert, z zastosowaniem ABL1 jako genu referencyjnego, zbadano materiał pochodzący od 125 pacjentów z CML-CP leczonych w pierwszej linii imatynibem, nilotynibem, dazatynibem lub bosutynibem. Nie wykryto istotnej różnicy w odsetkach odpowiedzi uzyskiwanych w 12. miesiącu terapii pomiędzy pacjentami, którzy w trzecim miesiącu terapii osiągnęli bądź też nie osiągnęli redukcji transkryptu BCR-ABL1 do $<10 \%$ (IS) CCyR uzyskano odpowiednio u 50\% i $86 \%(p=0,1)$, a MMR odpowiednio u $60 \%$ i $79 \%$ chorych $(p=0,21)$ ). Nowym, istotnym rokowniczo punktem odcięcia poziomu transkryptu w 3. miesiącu, adekwatnym dla metody GeneXpert okazał się poziom 1,6\% (IS). Pacjenci, którzy osiągnęli EMR na tym poziomie, mieli istotnie większe prawdopodobieństwo uzyskania w 12. miesiącu CCyR oraz MMR (odpowiednio 98\% i $54 \%$ [p $<0,001]$ oraz $88 \%$ i $56 \%$ [p $<0,001])$, a także mniejsze prawdopodobieństwo konieczności zmiany leczenia w przyszłości ( $16 \%$ vs $46 \%$ [p =0,005]) [20].

Nowym, obiecującym narzędziem służącym zarówno do jakościowej, jak i ilościowej oceny poziomu transkryptu BCR-ABL1 jest tzw. digital PCR (dPCR) [21]. dPCR bazuje na metodologii ilościowej reakcji PCR w czasie rzeczywistym (qPCR) z tradycyjną amplifikacją oraz opartą na fluorescencji detekcją produktu docelowego reakcji. Jednak dPCR pozwala na eliminację koniecznych w przypadku qPCR krzywych standardowych. Metoda ddPCR (droplet-digital PCR) oparta

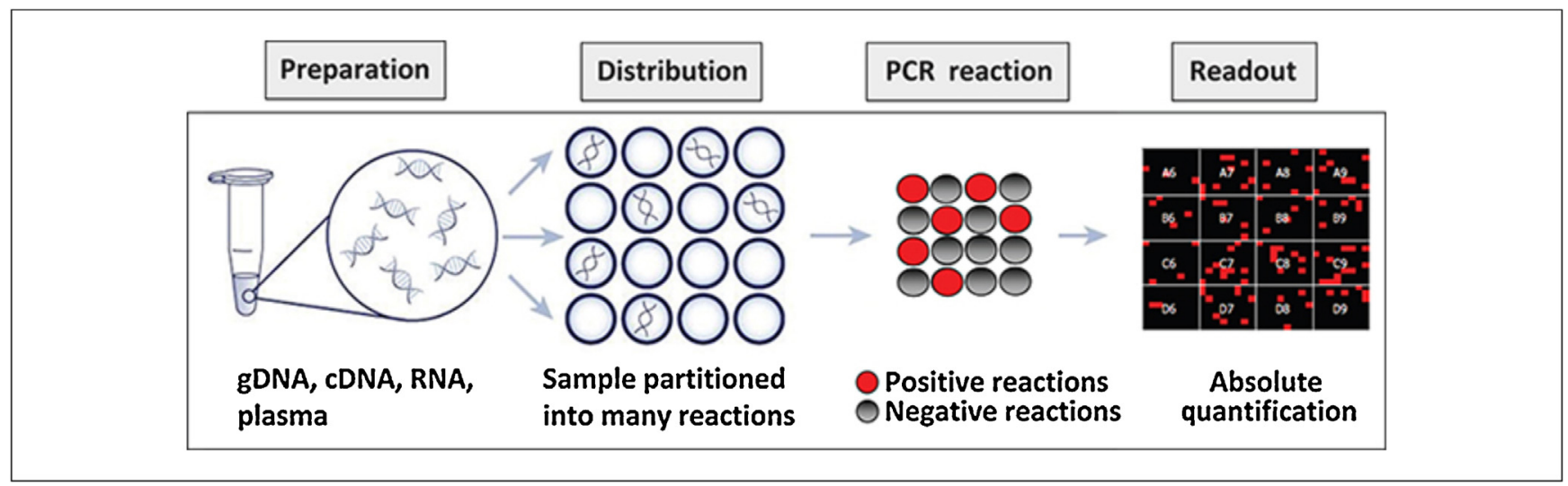

Ryc. 3 - Schemat działania dPCR. Etapy procesu: 1. Przygotowanie materiału do badania (jak do standardowej reakcji RQ-PCR) 2. Frakcjonowanie próbki na poszczególne reakcje. 3. Reakcja PCR 4. Odczyt i bezwzględna kwantyfikacja produktu z wykorzystaniem modelu statystycznego Poissona [22]

Fig. 3 - The schematic diagram of dPCR assay. Stages of the process: 1. Preparation of material (as in standard RQ-PCR assay). 2. Fractioning of the sample into single reactions. 3. PCR reaction. 4. Readout and absolute quantification of the product with the use of Poisson model [22] 
jest na technologii emulsyjno-kropelkowej, dzięki czemu pojedyncza próbka ulega w czasie rzeczywistym frakcjonowaniu na maksymalnie 20000 kropli (platforma diagnostyczna Bio-Rad QX-100), co umożliwia czułe i precyzyjne wykrywanie obecności w każdej z nich nawet pojedynczej cząsteczki DNA. System zlicza cząsteczki docelowe (dodatnie) oraz wszystkie pozostałe (negatywne), co pozwala na określenie przy użyciu analizy statystycznej Poissona bezwzględnej liczby cząsteczek docelowych w próbce, bez konieczności odniesienia do krzywych standardowych czy genu referencyjnego (Ryc. 3) [22-24]. Na rynku dostępne są też inne wersje dPCR, gdzie reakcja prowadzona jest na mikrochipach, lecz ogólna zasada działania pozostaje taka sama. Mimo niezaprzeczalnych zalet zastosowanie w chwili obecnej dPCR w ocenie poziomu transkryptu BCR-ABL1 do celów klinicznych wymaga znacznej rozwagi i doświadczenia. Badacze z Niemiec w dwóch laboratoriach akredytowanych przez EUTOS (Lipsk i Mannheim) przeprowadzili analizę porównawczą liczby transkryptu uzyskanej za pomocą metody qPCR oraz dPCR na 230 próbkach cDNA pochodzących od chorych na CML-CP, którzy uczestniczyli w badaniu ENEST1st. Zaobserwowali oni, że dPCR odczytuje większe poziomy transkryptu BCR-ABL1 niż qPCR i w związ$\mathrm{ku}$ z tym uzyskiwane odpowiedzi molekularne klasyfikowane są jako gorsze. Efekt ten był niezależny od ilości i jakości użytego materiału [25]. Biorąc pod uwagę, że wszystkie aktualne rekomendacje postępowania diagnostyczno-terapeutycznego opierają się na badaniach molekularnych wykonywanych metodą qPCR, wyniki badania dPCR używanego do celów klinicznych powinny być poddane wnikliwej ocenie i analizowane w porównaniu z wynikami uzyskanymi techniką qPCR w doświadczonych laboratoriach.

\section{Podsumowanie}

W leczeniu CML dokonał się bardzo istotny postęp. Jego odzwierciedleniem może być powstanie funkcjonującego od niedawna w literaturze pojęcia tzw. czynnościowego wyleczenia (functional cure) osiąganego $\mathrm{w}$ trakcie leczenia IKT [26]. W zakresie diagnostyki i monitorowania choroby istnieją nadal techniki, które poddawane są dalszym udoskonaleniom. Nie kwestionując bardzo istotnej rokowniczej roli EMR, nowy wskaźnik prognostyczny, którym jest HT, może okazać się bardzo przydatny i ułatwić podjęcie decyzji o zmianie leczenia IKT we wczesnym jego okresie, szczególnie $\mathrm{w}$ grupie pacjentów $\mathrm{z}$ poziomem transkryptu BCR-ABL1 $>10 \%$ w trzecim miesiącu,. Dzięki coraz większej dostępności takich narzędzi diagnostycznych, jak sekwencjonowanie eksomu czy transkryptomu, w przyszłości już w momencie diagnozy CML-CP możliwa będzie indywidualna analiza zmienności genetycznej u poszczególnych chorych i identyfikowanie pacjentów o największym ryzyku niekorzystnego przebiegu choroby. Tego typu metody, umożliwiając wgląd w zdarzenia molekularne towarzyszące progresji choroby czy też w mechanizmy oporności macierzystych komórek białaczkowych (LSC; leukemic stem cells) na działanie IKT, ułatwiają poszukiwanie nowych punktów uchwytu dla leczenia celowanego. Coraz bardziej precyzyjne i efektywne narzędzia do monitorowania poziomu transkryptu BCRABL1, takie jak dPCR pozwalają na jego wykrywanie z większą czułością i zwłaszcza w kontekście możliwości uzyskania długotrwałej odpowiedzi bez leczenia po jego odstawieniu mogą przyczynić się do dalszej poprawy wyników terapii u chorych na CML.

\section{Wkład autorów/Authors' contributions}

Według kolejności.

\section{Konflikt interesu/Conflict of interest}

TS pobierał honoraria za konsultacje od firm Novartis, BMS, Adamed, Angelini.

\section{Finansowanie/Financial support}

Nie występuje.

\section{Etyka/Ethics}

Treści przedstawione $\mathrm{w}$ artykule są zgodne $\mathrm{z}$ zasadami Deklaracji Helsińskiej, dyrektywami EU oraz ujednoliconymi wymaganiami dla czasopism biomedycznych

\section{P I ŚM I E N N I C T W O/REFERENCES}

[1] Melo JV, Barnes DJ. Chronic myeloid leukaemia as a model of disease evolution in human cancer. Nat Rev Cancer 2007;7(6):441-453.

[2] Hanfstein B, Mueller M, Erben P, et al. Molecular Response After 3 Months of 1st Line Imatinib Therapy Is Predictive for Treatment Failure and Disease Progression In Patients with Chronic Phase Chronic Myeloid Leukemia - a Follow-up Analysis of the German CML Study IV. Blood 2010. Abstract 360.

[3] Mahon FX, Rea D, Guilhot J, et al. Discontinuation of imatinib in patients with chronic myeloid leukaemia who have maintained complete molecular remission for at least 2 years: the prospective, multicentre Stop Imatinib (STIM) trial. Lancet Oncol 2010;11(11):1029-1035.

[4] Ross DM, Branford S, Seymour JF, et al. Safety and efficacy of imatinib cessation for CML patients with stable undetectable minimal residual disease: results from the TWISTER study. Blood 2013;122:515-522.

[5] Marin D, Ibrahim AR, Lucas C, et al. Assessment of BCRABL1 transcript levels at 3 months is the only requirement for predicting outcome for patients with chronic myeloid leukemia treated with tyrosine kinase inhibitors. J Clin Oncol 2012;30(3):232-238.

[6] Hughes TP, Saglio G, Kantarjian HM, et al. Early molecular response predicts outcomes in patients with chronic myeloid leukemia in chronic phase treated with frontline nilotinib or imatinib. Blood 2014;123(9): 1353-1360.

[7] Jabbour E, Kantarjian HM, Saglio G, et al. Early response with dasatinib or imatinib in chronic myeloid leukemia: 
3-year follow-up from a randomized phase 3 trial (DASISION). Blood 2014;123(4):494-500.

[8] Baccarani M, Deininger MW, Rosti G, et al. European LeukemiaNet recommendations for the management of chronic myeloid leukemia: 2013. Blood 2013;122(6): 872-884.

[9] National Comprehensive Cancer Network. NCCN clinical practice guidelines in oncology: chronic myelogenous leukemia. Version 1, 2014. http://www.nccn.org/ professionals/physician_gls/f_guidelines.asp. Assessed October 27, 2013.

[10] Sacha T, Lewandowski K, Hellman A, et al. Rekomendacje PALG dotyczące diagnostyki i leczenia przewlekłej białaczki szpikowej w 2013 r. Acta Haematol Pol 2013;44:345-362.

[11] Hanfstein B, Shlyakhto V, Lauseker M, et al. Optimizing early prediction of outcome in CML using the exact decline of BCR-ABL transcript levels within 3 months of imatinib treatment as a prognostic marker. Blood 2013;122(21):253.

[12] Branford S, Yeung DT, Parker WT, et al. Prognosis for patients with CML and $>10 \%$ BCRABL1 after 3 months of imatinib depends on the rate of BCR-ABL1 decline. Blood 2014;124:511-518.

[13] Branford S, Yeung DT, Ross DM, et al. The Adverse Effect of High Sokal Risk for First Line Imatinib Treated Patients Is Overcome By a Rapid Rate of BCR-ABL Decline Measured As Early As 1 Month of Treatment. Blood 2014;124(21):816.

[14] Branford S, Yeung DT, Prime JA, et al. BCRABL1 doubling times more reliably assess the dynamics of CML relapse compared with the BCR-ABL1 fold rise: implications for monitoring and management. Blood 2012;119(18): 4264-4271.

[15] Hanfstein B, Shlyakhto V, Lauseker M, et al. Velocity of early BCR-ABL transcript elimination as an optimized predictor of outcome in chronic myeloid leukemia (CML) patients in chronic phase on treatment with imatinib. Leukemia 2014;28:1988-1992.

[16] Iriyama N, Fujisawa S, Yoshida C, et al. Shorter halving time of BCR-ABL1 transcripts is a novel predictor for achievement of molecular responses in newly diagnosed chronic-phase chronic myeloid leukemia treated with dasatinib: Results of the D-first study of Kanto CML study group. Am J Hematol 2015;90:282-287.

[17] Marum JE, Purins L, Yeung DT, et al. Germline Genetic Variation of ASXL1 and BIM Predicts Response to Imatinib and Identifies a Subset of High Sokal Risk Patients with the Greatest Risk of Treatment Failure and Disease Progression. Blood 2015;126(23):475.

[18] Branford S, Wang PPS, Parker WT, et al. High Incidence of Mutated Cancer-Associated Genes at Diagnosis in CML Patients with Early Transformation to Blast Crisis. Blood 2015;126(23):600.

[19] Giustacchini A, Thongjuea S, Woll PS, et al. Single Cell Whole Transcriptome Analysis Reveals Distinct Molecular Signatures of Therapy-Resistant Chronic Myeloid Leukemia Stem Cells. Blood 2015.

[20] Garcia-Gutierrez V, Gomez Casares MT, Velasco Antonio J, et al. Molecular Response at 3 Months Measured with Genexpert BCR-ABL (IS) Platform Predicts Further Outcome in Chronic Myeloid Patients but the Cutoff Differs from the $10 \%$ Commonly Used with BCR-ABL (IS) EUTOS Method. Blood 2015;126(23):2776.

[21] Skyes PJ, Brisco MJ, Hughes E, et al. Quantitation of targets for PCR by use of limiting dilution. Biotechniques 1992 Sep;13(3):444-449.

[22] https://www.thermofisher.com/pl/en/home/life-science/ pcr/digital-pcr.html Assessed: April 1 1 2016.

[23] Pinheiro LB, ColemnVA, Hindson CM, et al. Evaluation of a Droplet Digital Polymerase Chain Reaction Format for DNA Copy Number Quantification. Anal Chem 2012;84 (2):1003-1011.

[24] Hindson BJ, Ness KD, Masquelier DA, et al. High-throughput droplet digital PCR system for absolute quantitation of DNA copy number. Anal Chem 2011;83:8604-8610.

[25] Franke GN, Maier J, Wildenberger K, et al. Quantification of BCR-ABL with Digital PCR Results in a Significantly Lower Rate of Deep Molecular Responses When Compared to RT-qPCR in CML Patients Treated in the ENEST1st Trial. Blood 2015.

[26] Cortes J, Goldman JM, Hughes T. Current issues in chronic myeloid leukemia: monitoring, resistance, and functional cure. J Natl Compr Canc Netw 2012;10(Suppl 3):S1-S13. 